\title{
Evaluation of polymerase chain reaction in the diagnosis of pulmonary tuberculosis in indigenous and non-indigenous patients*
}

\author{
ROSE MARY CORRÊA SANTOS', MAURICIO MORISHI OGUSKU², JOSÉ DE MORAES MIRANDA ${ }^{3}$, \\ MARIA CRISTINA DOS-SANTOS ${ }^{4}$ JULIA IGNEZ SALEM ${ }^{5}$
}

\begin{abstract}
Objective: To evaluate the accuracy of bacteriological methods and of polymerase chain reaction (with primers specific for 156110 of the Mycobacterium tuberculosis complex) in testing sputum samples from indigenous (Amerindian) and non-indigenous patients. Methods: A total of 214 sputum samples (154 from indigenous patients and 60 from nonindigenous patients) were analyzed in order to determine the accuracy of smear microscopy (direct and concentrated versions) for acid-fast bacilli, culture, and polymerase chain reaction. Results: Both microscopy methods presented low sensitivity in comparison with culture and polymerase chain reaction. Specificity ranged from $91 \%$ to $100 \%$, the concentrated acid-fast smear technique being the least specific. Nontuberculous mycobacteria were isolated three times more frequently in samples from indigenous patients than in those from non-indigenous patients. False-positive and false-negative polymerase chain reaction results were more common in the indigenous population. Conclusion: Positivity and isolation of nontuberculous mycobacteria in the acid-fast smear in conjunction with polymerase chain reaction positivity raise the following hypotheses: nontuberculous mycobacteria species with DNA regions homologous to, or even still possessing, the M. tuberculosis IS6110 exist in the Amazon; colonization of the oropharynx or of a tuberculous lesion accelerates the growth of the nontuberculous mycobacteria present in the sputum samples, making it impossible to isolate $M$. tuberculosis; A history of tuberculosis results in positivity for $M$. tuberculosis DNA. The absence of bacteriological positivity in the presence of polymerase chain reaction positivity raises questions regarding the inherent technical characteristics of the bacteriological methods or regarding patient history of tuberculosis.
\end{abstract}

Keywords: Tuberculosis, pulmonary/diagnosis; Mycobacterium tuberculosis, Polymerase chain reaction/methods; Indians, south american

\footnotetext{
* Study carried out at the National Research Institute of Amazônia, Universidade Federal do Amazonas (UFAM, Federal University of Amazonas) - Manaus, Amazonas, Brazil.

1. Pharmacist and Biochemist at the Hospital Universitário Getúlio Vargas (HUGV, Getúlio Vargas University Hospital) Manaus, Amazonas, Brazil.

2. Assistant Researcher at the Instituto Nacional de Pesquisas da Amazônia (INPA, National Research Institute of Amazônia) Manaus, Amazonas, Brazil

3. Physician at the Instituto Brasileiro para o Desenvolvimento Sustentável (IBDS, Brazilian Institute for Sustainable Development)

- São Gabriel da Cachoeira, Amazonas, Brazil

4. Adjunct Professor at the Universidade Federal do Amazonas (UFAM, Federal University of Amazonas) - Manaus, Amazonas, Brazil.

5. Head Researcher at the Instituto Nacional de Pesquisas da Amazônia (INPA, National Research Institute of Amazônia) Manaus, Amazonas, Brazil

Correspondence to: Julia lgnez Salem. Av. André Araújo, 2.936 - CEP 69060-001, Manaus, AM, Brazil.

Phone: 5592 3643-3058. E-mail: salem@inpa.gov.br

Submitted: 12 September 2005. Accepted, after review: 19 0ctober 2005.
} 


\section{INTRODUCTION}

Tuberculosis (TB) still constitutes a serious public health problem in Brazil. In 2002, 7061 new TB cases were registered in the Northern Region, reflecting an incidence of 52.29/100,000. The national mean for the aforementioned year was $48 /$ 100,000 . A total of 2194 cases were registered in the state of Amazonas, with an incidence of 74.08/ 100,000 , the greatest in the Northern Region. ${ }^{(1)}$

A more serious situation can be seen in the indigenous population of the region of the Cauaburis river (Upper Negro River/state of Amazonas), where 1455 indians of the Yanomami ethnic group live. In 2002, according to the data provided by the Brazilian Institute for Sanitary Development, 21 Yanomamis were treated for TB, which represents an incidence of 1443.3/100,000. Of these, 17 presented pulmonary forms of the disease, and four presented extrapulmonary forms of the disease. Among the pulmonary cases, acid-fast bacilli were detected by sputum smear microscopy in only $4(23.5 \%)$. The presumptive diagnosis of the other cases was based on strong pulmonary symptomatology or skin lesions that indicated cutaneous TB.

These results reflect the low concentration of bacilli in the pulmonary secretions of the indigenous patients, which had already been reported by other authors, ${ }^{(2)}$ who used the concentrated acid-fast smear technique and culture in Yanomami villages in the Marauia region. However, since no other method of high sensitivity and specificity was used, it is not possible to perform a comparative analysis to determine the efficacy of the culture.

Currently, among the new laboratory methods for TB diagnosis, the polymerase chain reaction (PCR) method stands out. This technique provides results in a period of time similar to that of sputum smear microscopy, using a mycobacteria concentration similar to that used for culture, and PCR is able to define the etiologic agent. ${ }^{(3-4)}$ In light of this, the objective of the present study was to evaluate PCR with oligonucleotides for the insertion sequence 6110 (IS6110) of the Mycobacterium tuberculosis complex in testing sputum samples from indigenous patients (Yanomamis from the Cauaburis River region) and non-indigenous patients (residing in the city of Manaus, located in the state of Amazonas). All of the patients experienced respiratory symptoms and were suspected of having pulmonary TB.

\section{METHODS}

In the year 2002, pulmonary secretions were collected from 60 non-indigenous patients and 158 indigenous patients, all of whom presented respiratory symptoms and were suspected of having pulmonary TB, residing in the state of Amazonas. A spontaneous sputum sample was collected from each patient and processed for the diagnosis of TB using bacteriological methods and PCR.

Of the total samples from indigenous patients, 110 were collected at the Casa do Índio (Indian House), located on the outskirts of the city of Manaus, and processed on the same day. The remaining 48 samples were collected in the village and a solution of cetylpyridinium chloride (decontaminating solution) was added to it immediately after the collection, as recommended by David et al. ${ }^{(5)}$ These samples were processed after five days, the time required to transport them from the indigenous village to the city of Manaus.

As a negative control for the PCR analysis, 20 other spontaneous sputum samples from patients with viral respiratory infections were incorporated. These samples were collected from patients with viral respiratory infections, treated at the Araújo Lima Outpatient Clinic of the Federal University of Amazonas in 2004. In these cases, the diagnosis of TB was ruled out by analyzing the samples using bacteriological methods (sputum smear microscopy and culture for mycobacteria) and by a clinical follow-up evaluation of at least six months.

The present study was approved by the Ethics in Research Committee of the National Research Institute of Amazônia and ratified by the Ethics in Human Research National Committee.

The 48 samples that were collected from indigenous patients were transported in cetylpyridinium chloride solution. They were then homogenized, and $0.2 \mathrm{~mL}$ of each sample was smeared on a microscope slide for the direct sputum smear microscopy. The remainder of each sample was centrifuged at $3500 \times \mathrm{g}$ for fifteen minutes. The supernatant was discarded and $2 \mathrm{~mL}$ of sterile water were added to the sediment. The $\mathrm{pH}$ of the suspension was adjusted with a hydrochloric acid sterile solution at $4 \%$, with the aid of the bromothymol blue indicator. Two drops were collected from the suspension and deposited, separately, on a microscope slide for analysis using the concentrated acid-fast smear technique. The remainder of the 
suspension was transferred for culture on LöwensteinJensen medium, and an aliquot of approximately 1 $\mathrm{mL}$ was stored at $-20^{\circ} \mathrm{C}$ for PCR analysis.

All the other samples were processed using direct sputum smear microscopy techniques, ${ }^{(6)}$ concentrated acid-fast smear technique, and culture for mycobacteria using sodium hydroxide as decontaminant and culture on Löwenstein-Jensen medium. ${ }^{(7)}$ Aliquots of $1 \mathrm{~mL}$ transferred from the decontaminated and neutralized sputum samples were stored at $-20^{\circ} \mathrm{C}$ for later PCR analysis. The cultures without mycobacterial growth were considered negative after a two-month period, and those with positive growth for acid-fast bacilli were subcultured for the performance of phenotype testing. The mycobacterial strains were primarily submitted to growth rate and pigment production tests. All of the non-chromogenic, slow-growth strains that produced niacin in the biochemical tests and strongly reduced nitrate to nitrite were identified as M. tuberculosis strains. ${ }^{(8)}$ The other strains were considered nontuberculous mycobacteria (NTM).

The DNA of the sputum samples, decontaminated and stored at $-20^{\circ} \mathrm{C}$, as well as the DNA of the M. tuberculosis strains isolated, was extracted according to the recommendations of Ogusku and Salem ${ }^{(9)}$ In each session, negative controls for DNA extraction were included, in order to rule out the possibility of cross-contamination among the samples.

The following oligonucleotides were used in the PCR test: 5'- CTC GTC CAG CGC CGC TTC GG - 3' and 5'- CCT GCG AGC GTA GGC GTC GG - 3', specifically for the amplification of a 123-bp insertion sequence (1S6110) fragment of the of the M. tuberculosis complex. ${ }^{(10)}$ Twenty $\mathrm{L}$ of the DNA extracted were added to a final volume of $50 \mathrm{~L}$ containing the reagents (Invitrogen) $20 \mathrm{mM}$ Tris$\mathrm{HCl} \mathrm{pH} \mathrm{8,4,} 50 \mathrm{mM} \mathrm{KCl}, 1.5 \mathrm{mM} \mathrm{MgCl} 2,200 \mathrm{M}$ of each dNTP, $0.1 \mathrm{M}$ of each oligonucleotide and $2 \mathrm{U}$ of Platinum ${ }^{\circledR}$ Taq DNA Polymerase. The amplification parameters consisted of a cycle at $94^{\circ} \mathrm{C}$ for $4^{\prime}, 35$ cycles at $94^{\circ} \mathrm{C}$ for $1^{\prime}, 66^{\circ} \mathrm{C}$ for $1^{\prime}, 72^{\circ} \mathrm{C}$ for $1^{\prime}$, and a final cycle at $72^{\circ} \mathrm{C}$ for 7 ', in a GeneAmp ${ }^{\circledR}$ PCR System 2400 thermocycler (Applied Biosystems).

A positive control containing $M$. tuberculosis H37Rv DNA, a negative control with Milli-Q sterile water, and the negative controls of DNA extraction were incorporated into each PCR session.

The determination of the efficacy of the extraction and integrity of the DNA, or of the presence of Taq DNA Polymerase inhibitors, was performed through amplifications with oligonucleotides -actin 5' (5' - AGC GGG AAA TCG TGC GTG - 3') and -actin 3' (5' - CAG GGT ACA TGG TGG TGC - 3'), which amplify a 304-bp segment of human $\beta$-actin DNA.(11) The amplification consisted of an initial cycle at $94^{\circ} \mathrm{C}$ for $4^{\prime}, 35$ cycles at $94^{\circ} \mathrm{C}$ for $1^{\prime}, 57^{\circ} \mathrm{C}$ for $1^{\prime}, 72^{\circ} \mathrm{C}$ for $1^{\prime}$, and a final cycle at $72^{\circ} \mathrm{C}$ for 7 '. The reagents in the respective concentrations were the same as those described for the $1 S 6110$ amplification, except for the oligonucleotides.

The amplified products were submitted to electrophoresis on a 1.5\% agarose gel and stained with ethidium bromide. They were viewed using an ultraviolet transilluminator and photographed using the Eagle Eye ${ }^{\circledR} 11$ system (Stratagene).

The results of sputum smear microscopy, culture, and PCR were compared, and culture or PCR was considered the gold standard. A $2 \times 2$ table was used to determine sensitivity and specificity. In order to determine the concordance between the diagnostic methods, we used the Kappa index, calculated using the BioEstat 2.0 program, ${ }^{(12)}$ and the interpretation was performed according to the recommendations of Pereira. ${ }^{(13)}$

\section{RESULTS}

All 20 sputum samples from individuals not suspected of having TB tested negative in the bacteriological tests (sputum smear microscopy and culture) and in the PCR for 1S6110, which indicated $100 \%$ co-negativity in the absence of mycobacteria.

Of the 218 samples collected from patients suspected of having TB, 4 were excluded from the study due to contamination of the culture tubes. The frequencies of positivity of each method, by ethnic origin of the populations studied, are presented in Table 1. The PCR results in the 214 samples analyzed, by bacteriological methods, are shown on Table 2 .

The results of the comparative analysis of accuracy (sensitivity and specificity) between the bacteriological methods, as well as the comparison of these with the PCR, are presented in Table 3. For the sake of accuracy between the PCR and the positive culture for M. tuberculosis, the quantitative data for samples with NTM were considered negative. In the PCR analysis, regarding the total 
TABLE 1

The frequencies of positivity of diagnostic methods for tuberculosis, in indigenous and non-indigenous populations

\begin{tabular}{lccccc}
\hline & \multicolumn{2}{c}{ Sputum smear microscopy } & \multicolumn{2}{c}{ Positive culture for } & \multicolumn{2}{c}{ PCR for } \\
Samples from: & Direct & concentrated & M. tuberculosis & NTM & IS6110 \\
\hline Non-indigenous & $15 / 60$ & $19 / 60$ & $38 / 60$ & $2 / 60$ & $34 / 60$ \\
& $(25.0 \%)$ & $(31.6 \%)$ & $(63.3 \%)$ & $(3.3 \%)$ & $(56.6 \%)$ \\
Indigenous & $0 / 154$ & $2 / 154$ & $6 / 154$ & $17 / 154$ & $28 / 154$ \\
& $(0 \%)$ & $(1.26 \%)$ & $(3.9 \%)$ & $(11.0 \%)$ & $(18.2 \%)$ \\
\hline
\end{tabular}

NTM: nontuberculous mycobacteria; PCR: polymerase chain reaction

TABLE 2

Distribution of PCR results by bacteriological methods, according to their ethnical origin

\begin{tabular}{lrrrrrrrrrrrrrr}
\hline & \multicolumn{1}{c}{ Culture on Löwenstein-Jensen medium } \\
PCR 1S6110 & M. tuberculosis & \multicolumn{1}{c}{ NTM } & \multicolumn{1}{c}{ Negative } \\
samples & \multicolumn{1}{c}{ DSSM } & CSSM & DSSM CSSM & DSSM & CSSM \\
& $\mathrm{P}$ & $\mathrm{N}$ & $\mathrm{P}$ & $\mathrm{N}$ & $\mathrm{P}$ & $\mathrm{N}$ & $\mathrm{P}$ & $\mathrm{N}$ & $\mathrm{P}$ & $\mathrm{N}$ & $\mathrm{P}$ & $\mathrm{N}$ \\
\hline Non- & $\mathrm{P}$ & 14 & 19 & 17 & 16 & 0 & 1 & 1 & 0 & 0 & 0 & 0 & 0 \\
indigenous N & 0 & 5 & 0 & 5 & 1 & 0 & 1 & 0 & 0 & 20 & 0 & 20 \\
Subtotals & 14 & 24 & 17 & 21 & 1 & 1 & 2 & 0 & 0 & 20 & 0 & 20 \\
lndigenous & $\mathrm{P}$ & 0 & 5 & 0 & 5 & 0 & 5 & 1 & 4 & 0 & 18 & 0 & 18 \\
& $\mathrm{~N}$ & 0 & 1 & 0 & 1 & 0 & 12 & 1 & 11 & 0 & 113 & 0 & 113 \\
Subtotals & 0 & 6 & 0 & 6 & 0 & 17 & 2 & 15 & 0 & 131 & 0 & 131 \\
\hline Totals & 14 & 30 & 17 & 27 & 1 & 18 & 4 & 15 & 0 & 151 & 0 & 151 \\
\hline PCR: polymerase chain & reaction; & NTM: nontuberculous \\
mycobacteria; DSSM: direct sputum smear microscopy; CSSM: \\
concentrated sputum smear microscopy; P: positive; N: negative.
\end{tabular}

isolation of mycobacteria, the positive cultures for M. tuberculosis were added to those of the NTM.

The concordances between the PCR results and the positive culture for M. tuberculosis by the Kappa index were 0.79 and 0.25 in samples of nonindigenous and indigenous patients, respectively.

\section{DISCUSSION}

When samples of indigenous populations are analyzed, their habits and customs should be taken into consideration. Attempting to protect themselves against diseases transmitted by insects, most indians change their names over time and live in closed environments. Consequently, the transmission of diseases caused by direct contamination is aggravated. Among these diseases is TB. The indians have the habit of chewing pieces of vegetation from the Amazon forest, which supposedly propitiate the introduction of an environmental microbiota into the oral cavity, unknown to science. It is possible to draw the conclusion that this habit is responsible for the fact that NTM were isolated three times more frequently in samples from indigenous patients than in those from non-indigenous patients, $11 \%$ and 3.3\%, respectively (Table 1 ).

TABLE 3

Accuracy of the laboratory methods of diagnosing TB in indigenous and non-indigenous populations

\begin{tabular}{|c|c|c|c|c|c|c|}
\hline \multirow{3}{*}{ Samples } & \multicolumn{4}{|c|}{ SENSITIVITY } & \multirow{3}{*}{$\begin{array}{c}\text { PCR/Culture } \\
\text { (MTb) }\end{array}$} & \multirow{3}{*}{$\begin{array}{l}\text { PCR/Culture } \\
(\mathrm{MTb}+\mathrm{NTM})\end{array}$} \\
\hline & \multicolumn{2}{|c|}{ SSM/NTM culture } & \multicolumn{2}{|c|}{ SSM/PCR } & & \\
\hline & Direct & Concentrated & Direct & Concentrated & & \\
\hline \multirow[t]{2}{*}{ Non-indigenous } & $14 / 38$ & $17 / 38$ & $14 / 34$ & $18 / 34$ & $33 / 38$ & $34 / 40$ \\
\hline & $(36.8 \%)$ & $(44.7 \%)$ & $(41.2 \%)$ & $(52.9 \%)$ & $(86.8 \%)$ & $(85.0 \%)$ \\
\hline Indigenous & $\begin{array}{l}0 / 6 \\
(0 \%)\end{array}$ & $\begin{array}{l}0 / 6 \\
(0 \%)\end{array}$ & $\begin{array}{l}0 / 28 \\
(0 \%)\end{array}$ & $\begin{array}{c}1 / 28 \\
(3.6 \%)\end{array}$ & $\begin{array}{c}5 / 6 \\
(83.3 \%)\end{array}$ & $\begin{array}{c}10 / 23 \\
(43.5 \%)\end{array}$ \\
\hline \multirow{3}{*}{ Samples } & \multicolumn{4}{|c|}{ ESPECIFICIDADE } & & \\
\hline & \multicolumn{2}{|c|}{ SSM/NTM culture } & \multicolumn{2}{|c|}{ SSM/PCR } & PCR/Culture & PCR/Culture \\
\hline & Direct & Concentrated & Direct & Concentrated & (MTb) & $(\mathrm{MTb}+\mathrm{NTM})$ \\
\hline \multirow[t]{2}{*}{ Non-indigenous } & $21 / 22$ & $20 / 22$ & $25 / 26$ & $25 / 26$ & $21 / 22$ & $20 / 20$ \\
\hline & $(95.5 \%)$ & $(91.0 \%)$ & $(96,2 \%)$ & $(96.2 \%)$ & $(95.5 \%)$ & $(100.0 \%)$ \\
\hline \multirow[t]{2}{*}{ Indigenous } & $148 / 148$ & $146 / 148$ & $126 / 126$ & $125 / 126$ & $125 / 148$ & $113 / 131$ \\
\hline & $(100 \%)$ & $(98.6 \%)$ & $(100 \%)$ & $(99.2)$ & $(84.5 \%)$ & $(86.3 \%)$ \\
\hline
\end{tabular}

Mtb: Mycobacterium tuberculosis; PCR: polymerase chain reaction; NTM: nontuberculous mycobacteria. 
Regarding the diagnostic tests for $\mathrm{TB}$, the absence of positivity for acid-fast bacilli among indigenous patients (Table 1), in the direct sputum smear microscopy results confirms the low sensitivity of the technique in this population. These results are independent of the location where this technique is used, whether it is performed in the indigenous area ${ }^{(2)}$ or in a specialized laboratory, ${ }^{(14)}$ as was the case in the present study.

Of the 38 samples containing $M$. tuberculosis, collected from the non indigenous population, only 14 tested positive in the direct sputum smear microscopy tests for M. tuberculosis isolates. This indicates that it was possible to establish the diagnosis of TB by direct sputum smear microscopy in only $36.8 \%$ of the samples studied, whereas $44.7 \%$ were detected by concentrated sputum smear microscopy (Table 3).

The low sensitivity of sputum smear microscopy in the samples studied was similar to that observed in patients infected with the human immunodeficiency virus $^{(15)}$ and lower than the mean levels reported in the data obtained from the Amazonas State Tuberculosis Control Program in the past five years. During this period, $63 \%$ of the new pulmonary cases tested positive in direct sputum smear microscopy. ${ }^{(16)}$ The analysis of these results is extremely important, since direct sputum smear microscopy, performed independently of the culture, is encouraged by the Ministry of Health as a laboratory test method for diagnosing TB throughout Brazil. This low sensitivity of sputum smear microscopy in the diagnosis of TB suggests that the mycobacterial culture should be used in the diagnosis routine, similar to what was recommended in the 11 Brazilian Consensus on Tuberculosis and incorporated by the Brazilian Ministry of Health for patients who are human immunodeficiency virus seropositive. ${ }^{(17)}$

Table 2 shows that direct and concentrated sputum smear microscopy revealed positivity for acid-fast bacilli and that NTM were isolated in both of the populations studied. It should be noted that false-positive results were only obtained for samples collected from non-indigenous patients. This has previously been reported ${ }^{(7)}$ and exposed as a possible NTM colonization of the oropharynx. In the present study, this result makes it possible to aggregate complementary hypotheses. Of the 5 samples with NTM isolation and positive sputum smear microscopy ( 1 in direct microscopy and 4 in concentrated microscopy), 2 presented PCR amplification for IS6110: 1 from a non-indigenous patient and 1 from an indigenous patient. The hypotheses raised are presented herein: the existence of NTM species in Amazônia that still possess $M$. tuberculosis 156110 , or a homology between DNA and the 156110 , similarly to reports by other authors. ${ }^{(18-19)}$ Another hypothesis would be the impossibility of isolating M. tuberculosis due to the rapid growth of the NTM present in the sputum samples (over 200 colonies isolates in each culture tube). This could be the result of an oropharynx colonization $^{(7)}$ or of the opportunistic colonization of a tuberculous lesion by NTM. Finally, a history of tuberculosis would result in positivity for M. tuberculosis DNA. ${ }^{(20-22)}$ In the present study, the non-indigenous patient presenting $1 S 6110$ had a history of TB, whereas the indigenous patient presenting 156110 did not report any disease in the past five years and could not recall any incident in the preceding years.

Table 2 shows that 5 samples of non-indigenous patients and 1 from an indigenous patient presented M. tuberculosis isolation with negative PCR, which represented $13.6 \%$ of the false-negative PCR results in the group studied. This is higher than the 5.6\% found by other authors, ${ }^{(9)}$ whose analyses were also performed in populations residing in the state of Amazonas, using the same technique adopted in the present study. Consequently, the percentage variation does not depend on the technique used or on the absence of the ${ }^{15} 6110$, since the PCR analysis of the strains provided positive results in $100 \%$ of the cases. It is logical to presume that the lower sensitivity of PCR in the present study resulted from the quality of the sample in relation to a possible interference of the human quantitative $D_{N A}{ }^{(23)}$ or from the microbiota of the respiratory tract, extracted simultaneously for the performance of PCR in clinical samples.

The lower than 100\% specificity between the PCR and the isolation of M. tuberculosis in the two groups studied (Table 3 ) is due to the presence of positive PCR in samples with isolated NTM. In the non-indigenous population, positivity of the concentrated sputum smear microscopy occurred in only 1 sample, as we have already presented and discussed. Of the 5 cases found in the indigenous population, only 1 presented positive concentrated sputum smear microscopy, also as previously 
discussed, and 4 presented negative sputum smear microscopy. In these 4 cases, a maximum of three colonies were isolated in all of the culture tubes, and there is no record of a history of TB in the past five years. These data rule out the hypothesis that, due to the more rapid growth of NTM, $M$. tuberculosis cannot be isolated in this population and reinforce the idea that environmental mycobacteria species exist in Amazônia, with regions homologous to M. tuberculosis $1 \mathrm{~S} 6110$ or related to the presence of $M$. tuberculosis DNA related to a history of TB. Unfortunately, it was not possible to perform the PCR in the NTM strains, since they were discarded after their correlation with the $M$. tuberculosis complex had been ruled out. It was observed that only 1 of the 4 cases reported presented a history of TB.

Only in the indigenous population did we find 18 patient samples that tested negative in the bacteriological tests and positive in the PCR. These findings indicate that these tests are not applicable in this population, since only 4 of these patients had a reported history of TB within the preceding five years.Despite the possibility of a history of TB in the other 14 cases, these data are impossible to access, since there are continuous, unregistered, name changes among this population, which makes it impossible to identify a history of TB in the records of the tuberculosis control programs. It is important to emphasize that this was a crosssectional study focused only on the bacteriological and molecular analysis of the clinical sample. Consequently, it analyzed the false positivity of PCR in sputum samples, not taking into consideration the clinical and radiologic findings of past or present periods, since these findings could reduce the proportion of false-positive PCR results. ${ }^{(24)}$ It is also possible that the absence of isolation of mycobacteria is related to technical issues, among which the unfeasibility of growth of few bacilli due to the contact with the solution of sodium hydroxide, used in the present study to decontaminate the samples. ${ }^{(25)}$

As a consequence of the greater incidence of NTM in the samples of indigenous patients, the concordance between the PCR results and the $M$. tuberculosis-positive culture was significantly inferior (0.25) to that obtained in the samples of non-indigenous patients (0.79). Consequently, for the analysis to represent an irrefutable finding, it would have to be aggregated to an analysis of clinical evolution and radiologic findings, in order to rule out, or not, the presence of active TB.

It is important to emphasize that the crosscontamination of DNA was ruled out as a hypothesis for false-positive PCR due to the use of disposable materials in all the stages of the procedures. In addition, none of the negative controls for DNA extraction of the sputum samples presented PCR positivity for $1 S 6110$.

Studies that are more comprehensive will be needed in order to explain some of the PCR results that we obtained for the indigenous population. Special attention should be given to the following items: analysis of samples from patients experiencing respiratory symptoms, with or without suspected $\mathrm{TB}$, and with a recorded history of previous diseases; imaging analysis of chest $\mathrm{X}$-rays and clinical followup should be used in order to confirm or rule out active TB; the use of culture methodologies that employ less drastic decontaminants (so that the feasibility of the bacillus is not affected) and culture mediums that are more propitious to the development of mycobacteria; PCR identification and analysis of all NTM strains isolated from indigenous samples; and PCR with primers for the 65-kDa sequence, since some authors have demonstrated ${ }^{(9)}$ that the sensitivity of such primers is similar to that of primers that amplify the 123-bp fragment of the $1 S 6110$ target.

\section{ACKNOWLEDGMENTS}

We are grateful to the Amazonas State Department of Health Tuberculosis Control Program for allowing us to access their data. We also wish to thank the professionals responsible for the Indian House, the National Indian Foundation, and the Brazilian Institute of Sanitary Development for their assistance in the collection of clinical samples. We would also like to thank Dr. Afrânio Lineu Kritski for the critical review of this article.

\section{REFERENCES}

1. Brasil. Ministério da Saúde. Programa Nacional de Controle da Tuberculose. Saúde reafirma que tuberculose é prioridade. [acesso 2005 Maio 14]. Brasília; Ministério da Saúde. Disponível em: http://portalweb02.saude.gov.br/ saude/visualizar_texto.cfm?idtxt=19974.

2. Sousa AO, Salem Jl, Lee FK, Vercosa MC, Cruaud P, Bloom 
BR, et al. An epidemic of tuberculosis with a high rate of tuberculin anergy among a population previously unexposed to tuberculosis, the Yanomami Indians of the Brazilian Amazon. Proc Natl Acad Sci USA. 1997;94(24):13227-32.

3. Hance AJ, Grandchamp B, Levy-Frebault V, Lecossier D, Rauzier J, Bocart D, et al. Detection and identification of mycobacteria by amplification of mycobacterial DNA. Mol Microbiol. 1989;3(7):843-9.

4. Abe C, Hirano K, Wada M, Kazumi Y, Takahashi M, Fukasawa $\mathrm{Y}$, et al. Detection of Mycobacterium tuberculosis in clinical specimens by polymerase chain reaction and Gen-Probe Amplified Mycobacterium Tuberculosis Direct Test. J Clin Microbiol. 1993;31(12):3270-4.

5. David H, Brum L, Prieto E. Manual de Micobacteriologia em Saúde Pública: princípios e métodos. Lisboa: Instituto de Higiene e Medicina Tropical; 1994.

6. Brasil. Ministério da Saúde. Coordenação Nacional de Doenças Sexualmente Transmissíveis e AIDS. Tuberculose - Diagnóstico Laboratorial - Baciloscopia [texto na Internet]. Brasília; Ministério da Saúde; 2001. [citado 2005 Fev 22]. Disponível em: http://www.aids.gov.br/telelab/ manual_2004.pdf.

7. Salem Jl, Marója MF, Marója MF, Carvalho FF de, Lima MO, Litaiff LRL, et al. Valor relativo do exame direto, após concentração e por cultivo de escarro no diagnóstico bacteriológico da tuberculose pulmonar no Amazonas. J Pneumol. 1990;16(3):133-6.

8. David HL, Levy-Frebault V, Thorel MF. Mèthodes de laboratoire pour mycobactériologie clinique. Paris: Comission des Laboratoires de Reference et d'Expertise de l'Institute Pasteur; 1989.

9. Ogusku MM, Salem Jl. Análise de diferentes primers utilizados na PCR visando ao diagnóstico da tuberculose no Estado do Amazonas. J Bras Pneumol. 2004;30(4):343-9.

10. Eisenach KD, Cave MD, Bates JH, Crawford JT. Polymerase chain reaction amplification of a repetitive DNA sequence specific for Mycobacterium tuberculosis. J Infect Dis. 1990;161(5):977-81.

11. Richter E, Schluter C, Duchrow M, Hahn M, RuschGerdes S, Galle J, et al. An improved method for the species-specific assessment of mycobacteria in routinely formalin-fixed and paraffin-embedded tissues. J Pathol. 1995;175(1):85-92.

12. Ayres M, Ayres Jr. M, Ayres DL and Santos AS. BioEstat 2.0: Aplicações estatísticas nas áreas das ciências biológicas e médicas. Belém: Sociedade Civil Mamirauá; Brasília: CNPq; 2000.

13. Pereira MG. Epidemiologia: teoria e prática. Rio de Janeiro: Guanabara Koogan; 2002.

14. Baruzzi RG, Barros VL, Rodrigues DR, Medeiros-de-Souza AC, Pagliaro H. Saúde e doença em índios Panará (KreenAkarôre) após vinte e cinco anos de contato com o nosso mundo, com ênfase na ocorrência de tuberculose
(Brasil Central). Cad Saúde Pública. 2001;17:407-12. 15. Kristki AL, Queiroz Mello FC, Barreto CEN, Pereira MM, Bravin $Y$, Vasconcelos G, et al. Fatores de risco associados à tuberculose pulmonar paucibacilar em pacientes atendidos em centros de saúde da cidade do Rio de Janeiro. Pulmão RJ. 2003;12(1):10-6.

16. Amazonas (Estado). Secretaria de Estado da Saúde. CREPS "Cardoso Fontes". Relatório de avaliação anual do Programa de Controle da Tuberculose no Amazonas [texto na Internet]. Diário Oficial do Município de Manaus, Manaus (AM); 2003. Disponivel em: http://www.manaus.am.gov.br/secretarias/ secretariaMunicipalDeAdministracaoEPlanejamento/ servicos/dom/2006/pdf/dom20061407cad1.pdf

17. Sociedade Brasileira de Pneumologia e Tisiologia. Consenso Brasileiro de Tuberculose: Diretrizes Brasileiras para Tuberculose 2004. J Bras Pneumol. 2004;30(Suppl 1):S57S86.

18. Kent L, McHugh TD, Billington 0, Dale JW, Gillespie SH. Demonstration of homology between $1 \mathrm{~S} 6110$ of Mycobacterium tuberculosis and DNAs of other Mycobacterium spp. J Clin Microbiol. 1995;33(9):22903. Erratum in: J Clin Microbiol 1995;33(11):3082. Comment in: J Clin Microbiol. 1996;34(5):1348-9.

19. McHugh TD, Newport LE, Gillespie SH. IS6110 homologs are present in multiple copies in mycobacteria other than tuberculosis-causing mycobacteria. J Clin Microbiol. 1997;35(7):1769-71. Comment in: J Clin Microbiol. 1998;36(3):853-4.

20. Thomsen V0, Kok-Jensen A, Buser M, Philippi-Schulz $\mathrm{S}$, Burkardt HJ. Monitoring treatment of patients with pulmonary tuberculosis: can PCR be applied? J Clin Microbiol. 1999;37(11):3601-7.

21. Diagnostic Standards and Classification of Tuberculosis in Adults and Children. This official statement of the American Thoracic Society and the Centers for Disease Control and Prevention was adopted by the ATS Board of Directors, July 1999. This statement was endorsed by the Council of the Infectious Disease Society of America, September 1999. Am J Respir Crit Care Med. 2000;161(4 Pt 1):1376-95.

22. Kaul KL. Molecular detection of Mycobacterium tuberculosis: impact on patient care. Clin Chem. 2001;47(8):1553-8.

23. Honoré-Bouakline S, Vincensini JP, Giacuzzo V, Lagrange $\mathrm{PH}$, Herrmann JL. Rapid diagnosis of extrapulmonary tuberculosis by PCR: impact of sample preparation and DNA extraction. J Clin Microbiol. 2003;41(6):2323-9.

24. Sloutsky A, Han LL, Werner BG. Practical strategies for performance optimization of the enhanced gen-probe amplified mycobacterium tuberculosis direct test. J Clin Microbiol. 2004;42(4):1547-51.

25. Toman K. Tomans tuberculosis: case detection, treatment, and monitoring. Questions and answers. 2nd ed. Geneva: World Health Organization; 2004. 